\title{
A Functional Polymorphism of Toll-Like Receptor 4 Gene Increases Risk of Gastric Carcinoma and Its Precursors
}

\author{
GEORGINA L. HOLD, ${ }^{*}$ CHARLES S. RABKIN, ${ }^{\ddagger}$ WONG-HO CHOW, ${ }^{\ddagger}$ MALCOLM G. SMITH, ${ }^{*}$ MARILIE D. GAMMON, ${ }^{\S}$ \\ HARVEY A. RISCH," THOMAS L. VAUGHAN, " KENNETH E. L. MCCOLL," JOLANTA LISSOWSKA, ${ }^{* \star}$ WITOLD ZATONSKI, ** \\ JANET B. SCHOENBERG, ${ }^{\ddagger \neq}$ WILLIAM J. BLOT, ${ }^{\S \S}$ N. ASHLEY G. MOWAT, ${ }^{\star}$ JOSEPH F. FRAUMENI JR, ${ }^{\ddagger}$ and \\ EMAD M. EL-OMAR* \\ *Department of Medicine and Therapeutics, Aberdeen University, Aberdeen, Scotland; ${ }^{\star}$ Division of Cancer Epidemiology and Genetics, National Cancer Institute, \\ Bethesda, Maryland; §Department of Epidemiology, University of North Carolina, Chapel Hill, North Carolina; "Department of Epidemiology and Public Health, Yale \\ University School of Medicine, New Haven, Connecticut; "Program in Epidemiology, Fred Hutchinson Cancer Research Center, and Department of Epidemiology, \\ University of Washington School of Public Health, Seattle, Washington; "Department of Medicine and Therapeutics, Glasgow University, Western Infirmary, Glasgow, \\ UK; **Division of Cancer Epidemiology and Prevention, Cancer Centre and M. Sklodowska-Curie Institute of Oncology, Warsaw, Poland; ${ }^{*}$ Applied Cancer \\ Epidemiology Program, New Jersey Department of Health and Senior Services, Trenton, New Jersey; and \$\$International Epidemiology Institute, Rockville, Maryland
}

Background \& Aims: TLR4 is a cell-surface signaling receptor involved in the recognition and host response to Helicobacter pylori. The $T L R 4+896 \mathrm{~A}>\mathrm{G}$ polymorphism linked with impaired reactivity to bacterial lipopolysaccharide may play a role in gastric carcinogenesis. Methods: We assessed associations with premalignant gastric changes in 149 relatives of gastric cancer patients, including 45 with hypochlorhydria and gastric atrophy. We also genotyped 2 independent Caucasian population-based case-control studies of upper gastrointestinal tract cancer, initially in 312 noncardia gastric carcinoma cases and 419 controls and then in 184 noncardia gastric carcinomas, 123 cardia carcinomas, 159 esophageal cancers, and 211 frequency-matched controls. Odds ratios were computed from logistic models and adjusted for potential confounding factors. Results: $T L R 4+896 \mathrm{G}$ carriers had an 11-fold (95\% confidence interval [CI], 2.5-48) increased odds ratio (OR) for hypochlorhydria; the polymorphism was unassociated with gastric acid output in the absence of $H$ pylori infection. Carriers also had significantly more severe gastric atrophy and inflammation. Seventeen percent of gastric carcinoma patients in the initial study and $15 \%$ of the noncardia gastric carcinoma patients in the replication study had 1 or 2 TLR4 variant alleles vs $8 \%$ of both control populations (combined OR $=2.3$; 95\% CI $=1.6-3.4)$. In contrast, prevalence of $T L R 4+896 \mathrm{G}$ was not significantly increased in esophageal squamous cell $(2 \%, \mathrm{OR}=0.2)$ or adenocarcinoma $(9 \%, \mathrm{OR}=1.4)$ or gastric cardia carcinoma $(11 \%$, $O R=1.4)$. Conclusions: Our data suggest that the TLR4+896A $>\mathrm{G}$ polymorphism is a risk factor for noncardia gastric carcinoma and its precursors. The findings underscore the role of the host innate immune response in outcome of $H$ pylori infection.

G astric cancer remains a major health problem despite the recent decline in the incidence of this malignancy in the developed world. The global burden is set to increase with around 1.1 million new cases ex- pected in the year $2010 .{ }^{1}$ Helicobacter pylori infection is the most recognized etiologic risk factor for this malignancy. ${ }^{2}$ The infection causes a chronic gastritis that is the precursor to all the pathophysiologic abnormalities characteristic of gastric carcinogenesis. ${ }^{3}$ The most important of these abnormalities are gastric atrophy and hypochlorhydria, which develop as a direct result of the chronic inflammation induced by the infection. ${ }^{4}$ However, these precancerous abnormalities only develop in a proportion of infected subjects that vary among different ethnic groups. The reason for the variable phenotypic expression of the infection is multifactorial, and combines the effects of the host genetic constitution, bacterial virulence factors, and environmental exposures.

We and others have recently reported that proinflammatory cytokine gene polymorphisms in the interleukin-1B (encoding IL-1 $\beta$ ), IL-1RN (encoding the naturally occurring receptor antagonist for IL-1 $\beta), I L-10$, and tumor necrosis factor alpha (TNF $\alpha)$, all contribute to increased risk of gastric carcinoma and its precursors (gastric atrophy and hypochlorhydria). ${ }^{5-9}$ These genetic risk markers belong to inflammation-related cytokines that exert their effect as part of the innate and adaptive immune response against the infection. Equally important in the appropriate handling of $H$ pylori infection are the receptors of the innate immune response. It is conceivable that functionally relevant polymorphisms in genes of such receptors could affect the magnitude and subsequent direction of the host's response against the infection.

Because the majority of $H$ pylori cells do not invade the gastric mucosa, this inflammatory response is triggered through contact of $H$ pylori with the gastric epithelia and subsequent injection of bacterial products into host

\footnotetext{
Abbreviations used in this paper: $\mathrm{Cl}$, confidence interval; GCR, gastric cancer patients; IL $\beta$, interleukin beta; LPS, lipopolysaccharide; OR, odds ratio; $\mathrm{PAO}_{\mathrm{pg}}$, pentagastrin stimulation; $\mathrm{PCR}$, polymerase chain reaction; TNF $\alpha$, tumor necrosis factor alpha; TRL4, Toll-like receptor 4. (c) 2007 by the AGA Institute $0016-5085 / 07 / \$ 32.00$ doi:10.1053/j.gastro.2006.12.026
} 
cells. ${ }^{10}$ Toll-like receptor 4 (TLR4), the lipopolysaccharide (LPS) receptor, was initially identified as a potential binding receptor for $H$ pylori on gastric epithelial cells, although more recent data are controversial. It is more likely that interaction with macrophage/monocyte TLR4 is more relevant for $H$ pylori infection. TLR4 belongs to a family of pattern recognition receptors, of which there are currently 11 members, that activate pro-inflammatory signaling pathways in response to microbes or pathogenassociated molecular patterns. ${ }^{11}$ TLR4, in conjunction with CD14 and MD-2, transduces signals through MyD88, Toll/IL-1 receptor domain, and TRAF6. This promotes transcription of genes, which are involved in immune activation including the transcription factor nuclear factor $\kappa-\mathrm{B}(\mathrm{NF}-\kappa \mathrm{B})$ and also mitogen-activated protein (MAP) kinase pathways. ${ }^{12}$

Recently, a functional polymorphism at position +896 in exon 4 of the TLR4 gene has been described (dbSNP ID: rs 4986790). ${ }^{13}$ This $A>G$ transition results in replacement of a conserved aspartic acid residue with glycine at amino acid 299 (Asp299Gly), and alteration in the extracellular domain of the TLR4 receptor. This renders carriers hyporesponsive to LPS challenge by either disrupting transport of TLR4 to the cell membrane or by impairing ligand binding or protein interactions. ${ }^{13}$ The mutation has been associated with a variety of inflammatory, infectious and neoplastic conditions including atherosclerosis, myocardial infarction, inflammatory bowel disease, septic shock, and prostate cancer. ${ }^{14-19}$ Recent work demonstrates that defective signaling through the TLR4 receptor ultimately leads to an exaggerated inflammatory response with severe tissue destruction, even though the initial immune response may be blunted. This is due to inadequate production of IL-10secreting type 1 regulatory cells. ${ }^{20}$

Thus, we hypothesized that the TLR4 $+896 \mathrm{~A}>\mathrm{G}$ polymorphism would be associated with an exaggerated and destructive chronic inflammatory phenotype in $\mathrm{H}$ pyloriinfected subjects. This phenotype would be characterized by gastric atrophy and hypochlorhydria, the hallmarks of subsequent increased risk of gastric carcinoma. We further hypothesized that the same polymorphism might increase the risk of gastric carcinoma itself. The aim of our study was therefore to test the effect of this polymorphism on the $H$ pylori-induced gastric phenotype and the risk of developing premalignant and malignant outcomes.

\section{Materials and Methods \\ Study Populations}

To determine whether the TLR4 $+896 \mathrm{~A}>\mathrm{G}$ polymorphism is associated with differing outcomes of $H$ pylori infection, we studied a cohort of 149 healthy Caucasian first-degree relatives of gastric cancer patients (GCR) from the West of Scotland. These subjects had been extensively investigated in relation to their $H$ pylori status (assessed by ${ }^{14} \mathrm{C}$-urea breath test, serology, rapid slide urease test, culture, and histology). Their gastric phenotype was defined histologically by assessment of antral and corpus biopsies for $H$ pylori density, combined inflammatory scores (active and chronic giving a maximum score of 6 , range $0-6$ ), and presence of mucosal atrophy (score $0-3$ ). ${ }^{21}$ In addition, these subjects had their peak acid output measured in response to pentagastrin stimulation $\left(\mathrm{PAO}_{\mathrm{pg}}\right)$ and the subjects were designated as having hypochlorhydria if their $\mathrm{PAO}_{\mathrm{pg}}$ was $<15$ $\mathrm{mmol} / \mathrm{h} .{ }^{22}$ Corpus atrophy was absent in all subjects with a $\mathrm{PAO}_{\mathrm{pg}} \geq 15 \mathrm{mmol} / \mathrm{h}$. The 149 subjects were then classified into 3 distinct groups: (1) 45 subjects had $H$ pylori infection, hypochlorhydria, and gastric atrophy; (2) 58 subjects had $H$ pylori infection but no hypochlorhydria or corpus atrophy; (3) 46 subjects had no evidence of $H$ pylori infection and had normal acid secretion and gastric morphology. One hundred unselected cord blood DNA samples from the West of Scotland were used as population controls for the genetic studies. Data were available to allow assessment of the effect of the TLR4 genotype on histologic and physiologic parameters in addition to estimating the risk of each outcome.

To assess the effect of the polymorphisms on the risks of upper gastrointestinal tract cancers, 2 independent case-control studies were utilized. The first was a gastric cancer case-control study derived from a Caucasian population in Warsaw, Poland, in which there were DNA samples available from 312 noncardia gastric adenocarcinoma patients and 419 controls. $^{23}$ The second was a multicenter esophageal and gastric cancer study conducted in 3 geographic areas of the United States with population-based tumor registries ${ }^{24}$; DNA samples were available from 307 subjects with gastric adenocarcinoma (123 cardia and 184 noncardia, 90\% Caucasian), 159 subjects with esophageal cancer (52 with squamous cell carcinoma and 107 with adenocarcinoma, 90\% Caucasian), and 211 population controls (94\% Caucasian).

\section{Genotyping}

The TLR4 $+896 \mathrm{~A}>\mathrm{G}$ polymorphism was initially assessed in the GCR subjects using the restriction fragment length polymorphism assay described by Lorenz. ${ }^{25}$ Briefly, the locus was amplified by polymerase chain reaction (PCR), with 1 PCR primer altered to create an NcoI restriction site for the variant $G$ amplicon (Table 1). Reactions were performed in a volume of $25 \mu \mathrm{L}$ containing $50 \mathrm{ng}$ of DNA, $10 \mathrm{mmol} / \mathrm{L}$ Tris- $\mathrm{HCl} \mathrm{pH} 9.0,50$ $\mathrm{mmol} / \mathrm{L} \mathrm{KCl} ; 1.5 \mathrm{mmol} / \mathrm{L} \mathrm{MgCl}, 200 \mu \mathrm{mol} / \mathrm{L}$ each of deoxyadenosine triphosphate, deoxycytidine triphosphate (dTTP), and deoxyguanosine triphosphate, 10 pmol of each primer (MWG Biotech, Germany), and 1 unit of Taq polymerase (Bioline, London, England). Reactions were run on a Techne Genius thermocycler (Techne, Cambridge, England) using the following con- 
Table 1. Sequences of Primers and Probes Used in Genotyping Assays

\begin{tabular}{cll}
\hline Assay & \multicolumn{1}{c}{ Primers } & \multicolumn{1}{c}{ Probes } \\
\hline RFLP & F: 5'-GATTAGCATACTTAGACTACTACCTCCATG-3 ${ }^{a}$ & No probes \\
& R: 5'-GATCAACTTCTGAAAAAGCATTCCCAC-3' & \\
TaqMan & F: 5'- TGACCATTGAAGAATTCCGATTAGCA & VIC: TACCTCGATGATATTATT \\
& R: 5'- CACCAGGGAAAATGAAGAAACATTTGT & FAM: CCTCGATGGTATTATT \\
\hline
\end{tabular}

$\mathrm{F}$, forward primer; R, reverse primer; RFLP, restriction fragment length polymorphism.

anderlined base in primer indicates the nucleotide altered to create a $\mathrm{Ncol}$ restriction site.

ditions: $95^{\circ} \mathrm{C}$ for 4 minutes, then 30 cycles of $95^{\circ} \mathrm{C}$ for 30 seconds, $55^{\circ} \mathrm{C}$ for 30 seconds, and $72^{\circ} \mathrm{C}$ for 30 seconds, followed by a final extension of $72^{\circ} \mathrm{C}$ for 10 minutes. Five microliters of the resultant PCR products were used for an overnight digest with the restriction enzyme $\mathrm{NcoI}$ (New England Biolabs, Herts, England). Digestion products were separated by electrophoresis on $2.5 \%$ agarose gels.

All the GCR genotypes were subsequently confirmed with a $5^{\prime}$ nuclease PCR assay (Taqman), using minor groove binding probes 5 '-labeled with FAM (6-carboxyfluoresceine) or VIC fluorochromes to detect the G or A allele, respectively (Table 1). PCR amplification was performed in a volume of $25 \mu \mathrm{L}$ containing $50 \mathrm{ng}$ genomic DNA, $1 \times$ TaqMan Universal Master Mix (PE Applied Biosystems, Foster City, CA), $200 \mathrm{nmol} / \mathrm{L}$ for each probe, and $900 \mathrm{nmol} / \mathrm{L}$ for primers. Thermal cycling of optical plates was performed on a GeneAmp PCR System 9700 (PE Applied Biosystems) using the following conditions: $50^{\circ} \mathrm{C}$ for 2 minutes, $95^{\circ} \mathrm{C}$ for 10 minutes, then 40 cycles of $95^{\circ} \mathrm{C}$ for 15 seconds and $60^{\circ} \mathrm{C}$ for 1 minute. Endpoint analysis was performed in an ABI PRISM 7700 Sequence Detection System (PE Applied Biosystems). Genotyping for the gastric cancer case-control studies was done using the restriction fragment length polymorphism and Taqman assays for all samples with 100\% concordance. Both assays were validated by direct sequencing of selected samples of each genotype.

\section{Statistical Analysis}

The effect of the TLR4+896 A $>\mathrm{G}$ polymorphism on acid secretory status and histologic parameters (inflammation and atrophy) in the GCR study was assessed using the Mann-Whitney $U$ test with significance taken at the $5 \%$ level.

Hardy-Weinberg equilibrium of alleles at individual loci was assessed by $\chi^{2}$ statistics. Odds ratios (OR) with Cornfield 95\% confidence intervals (CIs) were computed by logistic regression using STATA version 7.0 software (STATA Press, College Station, TX). ORs for hypochlorhydria in the GCR study were age adjusted (categorized as $\leq 35,36-45,46-55$, and $>55$ years) because of its age dependence, ${ }^{22}$ and their CIs were based on robust variance estimates, ${ }^{26}$ adjusted for within-family correlation, to account for sampling of several members of a given family. ORs for the different cancers were adjusted for age (categorized as younger than 50, 50-59, 60-69, and 70 years or older), sex, and race (categorized as White and all other). Additional models were adjusted for the effects of the genetic polymorphisms on one another, histologic subtype (Lauren classification), cigarette smoking (categorized as current, former, and never), alcohol consumption (categorized as greater or less than 1 drink per month), history of gastroesophageal reflux disease, body mass index (in quartiles), history of gastric or duodenal ulcer disease, $H$ pylori serologic status, and family history of esophageal or gastric cancer.

The institutional review boards of the participating centers approved the study, and written informed consent was obtained from all subjects.

\section{Results}

In all 3 control populations, the alleles at the TLR4+896 locus were in Hardy-Weinberg equilibrium, With nonsignificant $\chi^{2}$ values. The frequency of the variant allele in the 3 control populations ranged from 3.9\% to $4.3 \%$, and was similar to those reported from other studies of Caucasians. The homozygous TLR4+896 G/G genotype was rare, and the $\mathrm{A} / \mathrm{G}$ and $\mathrm{G} / \mathrm{G}$ carrier genotypes were combined in the genetic association analyses.

\section{Association of TLR4+896A>G Polymorphism With Risks of $\mathrm{H}$ pylori Infection and Premalignant Gastric Abnormalities}

The TLR4 polymorphism was not associated with risk of $H$ pylori infection in the GCR study. Comparing all infected subjects (with and without precancerous abnormalities) to noninfected subjects, the adjusted OR for infection was 1.2 (95\% CI, 0.4-4.0).

There was a significantly higher frequency of the variant $\mathrm{G}$ allele in $H$ pylori-infected subjects with hypochlorhydria and gastric atrophy, compared to infected GCR with neither abnormality. Thirteen (29\%) of the 45 GCR with hypochlorhydria and atrophy were variant carriers compared with only 2 (3\%) of 58 infected subjects without these precancerous changes. The odds ratio of hypochlorhydria/atrophy for carriers of the $\mathrm{G}$ allele was 11.0 (95\% CI, 2.5-48), adjusted for age and multiple sampling from the same family (Table 2).

Among the $103 \mathrm{H}$ pylori-positive GCR, the 15 carriers of the TLR4+896 G allele had significantly lower $\mathrm{PAO}_{\mathrm{pg}}$ 
Table 2. Genotype Frequencies and Adjusted Odds Ratios (ORs) (and Cornfield 95\% Confidence Intervals [Cls]) for the TLR4+896A $>$ G Polymorphism in Gastric Cancer Relatives (GCR) and Population Controls

\begin{tabular}{|c|c|c|c|c|c|c|}
\hline \multirow[b]{2}{*}{ Genotype } & \multicolumn{2}{|c|}{$H$ pylori positive GCR } & \multirow[b]{2}{*}{ OR $(95 \% \mathrm{Cl})^{a}$} & \multirow{2}{*}{$\begin{array}{l}H \text { pylori negative GCR } \\
(\mathrm{n}=46)\end{array}$} & \multirow[b]{2}{*}{ OR $(95 \% \mathrm{CI})^{b}$} & \multirow{2}{*}{$\begin{array}{l}\text { Population controls } \\
\qquad(n=100)\end{array}$} \\
\hline & Low acid/atrophy $(n=45)$ & Normal/high acid $(\mathrm{n}=58)$ & & & & \\
\hline $\mathrm{A} / \mathrm{A}$ & 32 & 56 & 1.0 & 42 & 1.0 & 92 \\
\hline$A / G$ & 13 & 2 & $11(2.5-48)$ & 4 & $0.9(0.2-3.8)$ & 8 \\
\hline $\mathrm{G} / \mathrm{G}$ & 0 & 0 & & 0 & & 0 \\
\hline
\end{tabular}

${ }^{a}$ Odds ratio for low acid vs normal/high acid, adjusted for age and within-family sampling.

${ }^{b} \mathrm{OR}$ for $H$ pylori-positive GCR vs $H$ pylori-negative GCR.

compared with the 88 noncarriers (median of 1.1 $\mathrm{mmol} / \mathrm{h}$ vs. $23.2 \mathrm{mmol} / \mathrm{h}, P<.001$ ) (Figure 1 ). Within the subgroup of 45 GCR with hypochlorhydria and atrophy, the TLR4+896 G carriers had more severe histologic changes than did the noncarriers. The median combined corpus inflammatory score was 6 (range: 4-6) for the 13 carriers vs. 4 (range: $3-6$ ) for the 32 noncarriers, and the median atrophy score was 2 (range: $1-3)$ for the carriers vs. 1 (range: $1-3)$ for the noncarriers $(P<.03$ and $P<.02$, respectively; Figures $2 A$ and $B)$.

\section{Association of TLR4+896A>G Polymorphism With Risk of Gastric Carcinoma}

The TLR4+896 G allele was similarly associated with the risk of gastric carcinoma. In the Polish study, $17 \%$ of the gastric carcinoma patients had 1 or 2 TLR 4 variant alleles vs. $8 \%$ of control subjects (Table 3 ). The age, sex-adjusted OR of noncardia gastric cancer for carriers of the $\mathrm{G}$ allele was 2.5 (95\% CI, 1.6-4.0).
The association with noncardia gastric cancer was confirmed in the multicenter U.S. study. Fifteen percent of cases had at least 1 copy of the variant TLR4+896G allele, compared with only $8 \%$ of the control population (OR = 2.1, 95\% CI, 1.1-4.2; Table 3). However, the polymorphism was not significantly associated with risk of the other upper gastrointestinal cancers. TLR4+896 G was present in $11 \%$ of subjects with gastric cardia carcinoma $(\mathrm{OR}=1.4,95 \% \mathrm{CI}, 0.6-3.0), 9 \%$ of esophageal adenocarcinoma $(\mathrm{OR}=1.4,95 \% \mathrm{CI}, 0.6-3.2)$, and $2 \%$ of esophageal squamous cell carcinoma $(\mathrm{OR}=0.2,95 \% \mathrm{CI}, 0.02$ 1.7; Table 4).

For increased precision of the effect estimate for noncardia gastric carcinoma, we combined the data from the 2 case-control studies. With a total of 496 cases and 630 controls, the combined adjusted OR for noncardia gastric carcinoma was 2.3 (95\% CI, 1.6-3.4; Table 3). The ORs for noncardia gastric carcinoma did not significantly differ between the intestinal $(\mathrm{OR}=2.2,95 \% \mathrm{CI}, 1.4-3.4)$

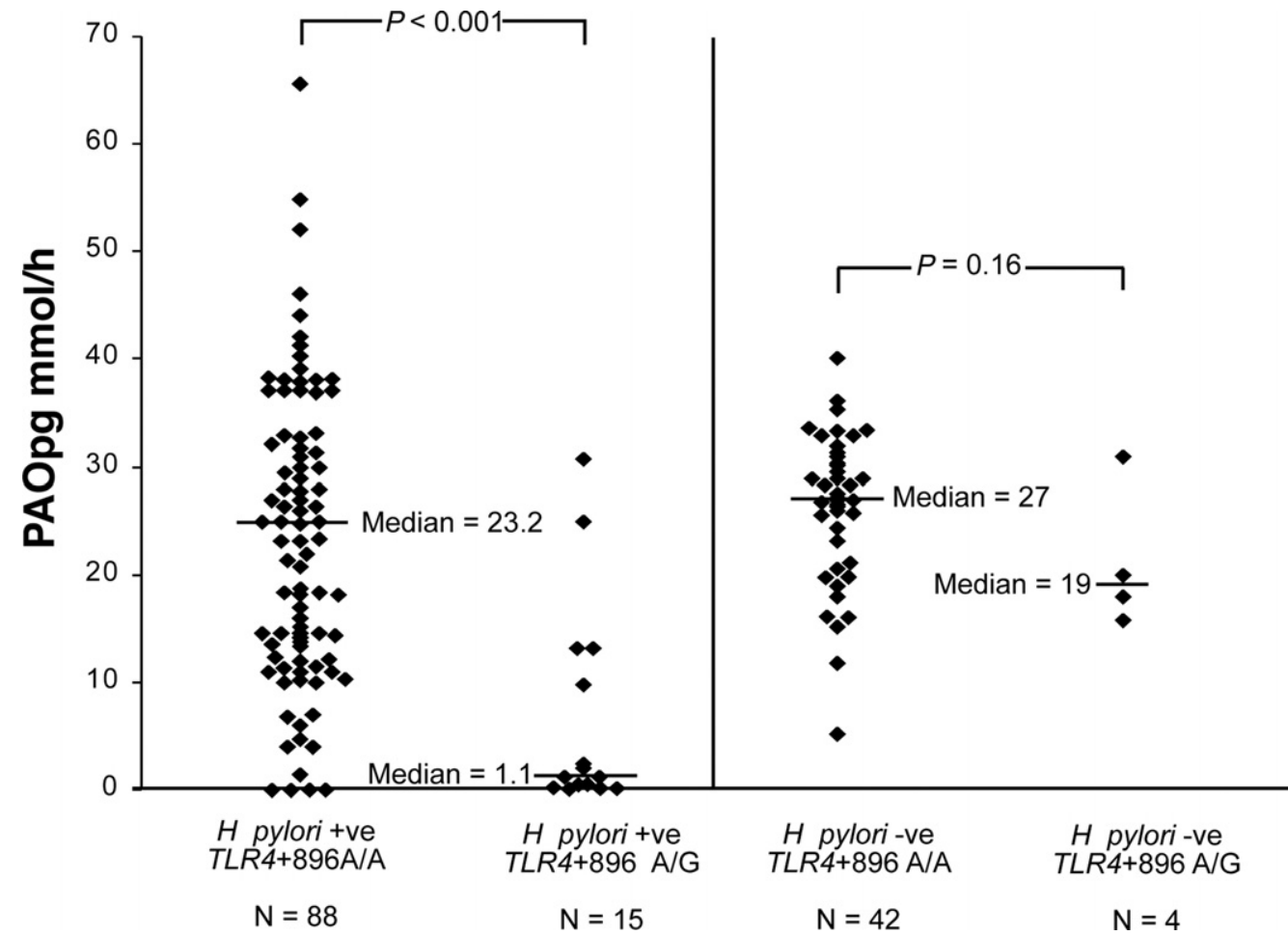

Figure 1. Peak acid output to pentagastrin $\left(\mathrm{PAO}_{\mathrm{pg}}\right)$ stimulation for $H$ pylori-positive and -negative subjects stratified by TLR4+896 genotype. 

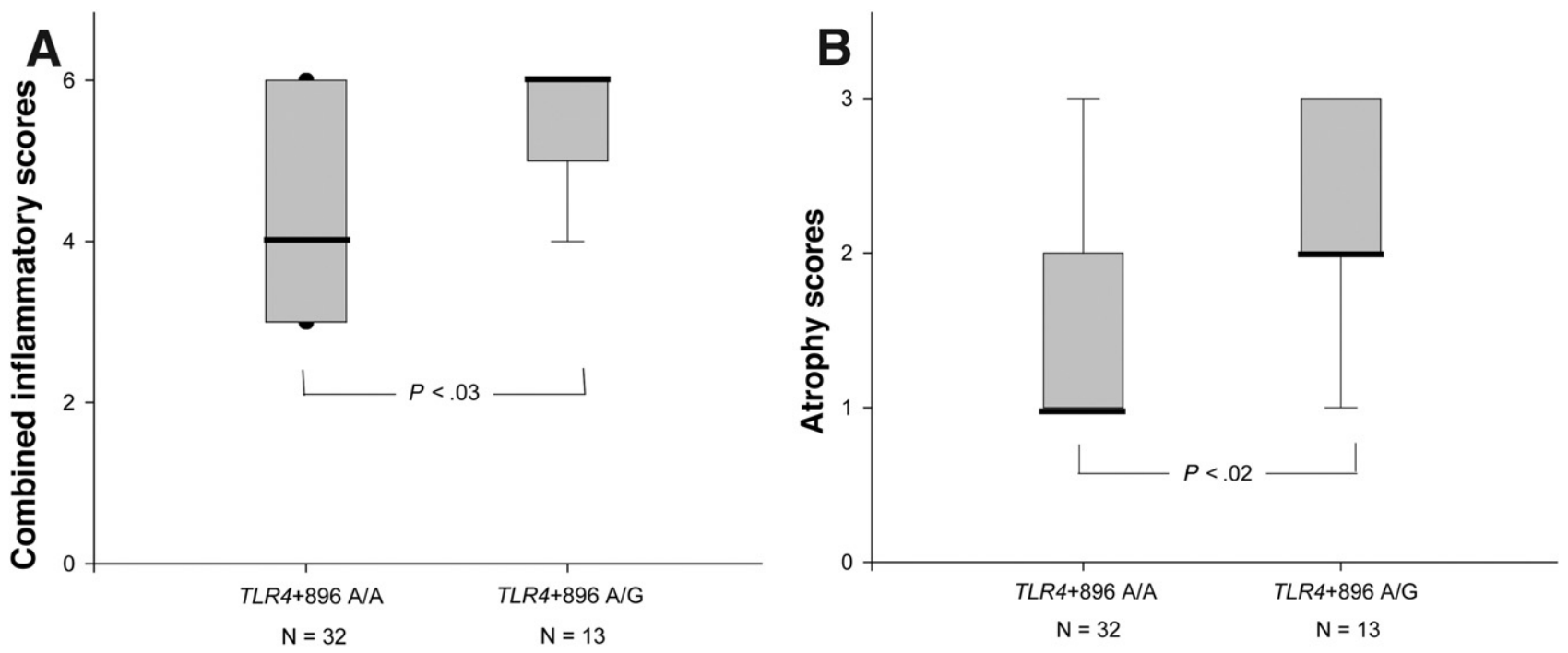

Figure 2. (A) Box-and-whisker plot of combined inflammatory scores in $H$ pylori +ve subjects with hypochlorhydria and atrophy stratified on the basis of TRL4+896 A>G polymorphism. The bold lines represent medians, and the span of the box represents the interquartile range of the data. The whiskers of the plot include outliers. (B) Box-and-whisker plot of atrophy scores in $H$ pylori + ve subjects with hypochlorhydria and atrophy stratified on the basis of $T L R 4+896 \mathrm{~A}>\mathrm{G}$ polymorphism. The bold lines represent medians, and the span of the box represents the interquartile range of the data. The whiskers of the plot include outliers.

and diffuse $(\mathrm{OR}=3.0,95 \% \mathrm{CI}, 1.8-5.1)$ types of gastric carcinoma.

\section{Combined Effect of TLR4+896A>G and Proinflammatory IL-1 Polymorphisms on Risk of Noncardia Gastric Carcinoma}

As previously reported, carriage of the pro-inflammatory $I L-1 B-511 \mathrm{~T}$ allele and homozygosity for allele 2 of the $I L-1 R N$ VNTR are associated with increased risk of gastric carcinoma. The independent effect of TLR4+896 $A>G$ was similar in models that included these markers of cytokine genes (data not shown). In a model combining these 2 types of markers, the ORs for gastric carcinoma in the presence of neither, an IL-1 pro-inflammatory genotype alone, carriage of TLR4+896 G alone, or both an $I L-1$ pro-inflammatory genotype and TLR4+896 G were 1.0, 2.4, 3.0, and 5.0, respectively (Table 5).

\section{Discussion}

In the present study, we have shown that a functional TLR4 polymorphism is associated with the development of the premalignant gastric abnormalities of hypochlorhydria and atrophy, and also with increased risk of noncardia gastric carcinoma. The association with noncardia gastric carcinoma was confirmed in 2 independent population-based case-control studies. No association was seen with cancer of the cardia or esophagus. Although this polymorphism has been associated with risk of other inflammatory conditions, to our knowledge this is the first report of an association with gastric carcinoma and its precursors and the first to show associations between gastric carcinoma and a toll-like receptor gene, a classic example of the innate immune response. The magnitude of the increased risk, a combined OR for the 2 studies of 2.3 , is entirely in keeping with a modest genetic contribution to a complex and multifactorial human cancer. The polymorphism had no impact on the risk of $H$ pylori infection itself, but the findings underscore the importance of host genetic factors in determining the clinical outcome of the infection. They also shed considerable light on the pathogenesis of $H$ pylori-induced gastric carcinoma and the role of the innate immune response in it.

The association of the TLR4 $+896 \mathrm{~A}>\mathrm{G}$ polymorphism with both gastric carcinoma and its precursor lesions implies that it is relevant to the entire multistage process

Table 3. Genotype Frequencies and Age-, Sex-, Race-Adjusted Odds Ratios (ORS) (and Cornfield 95\% Confidence Intervals [Cls]) for the TLR4+896A > G Polymorphism in Noncardia Gastric Carcinoma Cases and Controls, Polish and US Studies

\begin{tabular}{|c|c|c|c|c|c|c|c|}
\hline Genotype & $\begin{array}{l}\text { Polish controls } \\
\qquad(n=419)\end{array}$ & $\begin{array}{c}\text { Polish cases } \\
(n=312)\end{array}$ & OR $(95 \% \mathrm{Cl})$ & $\begin{array}{l}\text { US controls } \\
(n=211)\end{array}$ & US cases $(n=184)$ & OR (95\% Cl) & $\begin{array}{l}\text { Combined OR } \\
\qquad(95 \% \mathrm{Cl})\end{array}$ \\
\hline $\mathrm{A} / \mathrm{A}$ & 387 & 258 & 1.0 & 194 & 156 & 1.0 & 1.0 \\
\hline $\mathrm{A} / \mathrm{G}$ & 31 & 51 & $2.5(1.6-4.0)$ & 16 & 28 & $2.1(1.1-4.2)$ & $2.3(1.6-3.4)$ \\
\hline$G / G$ & 1 & 3 & & 1 & 0 & & \\
\hline
\end{tabular}


Table 4. Genotype Frequencies and Adjusted Odds Ratios (ORs) (and Cornfield 95\% Confidence Intervals [Cls]) for Carriers of the TLR4+896 G Allele in Patients With Esophageal or Gastric Cardia Cancer and Controls, U.S. Study

\begin{tabular}{|c|c|c|c|c|c|c|c|}
\hline Genotype & $\begin{array}{l}\text { Controls } \\
(\mathrm{n}=211)\end{array}$ & $\begin{array}{l}\text { Esophageal squamous cell } \\
\qquad(\mathrm{n}=52)\end{array}$ & OR (95\% Cl) & $\begin{array}{l}\text { Esophageal } \\
\text { adenocarcinoma } \\
(n=107)\end{array}$ & OR (95\% Cl) & $\begin{array}{l}\text { Gastric cardia } \\
\text { adenocarcinoma } \\
(n=123)\end{array}$ & OR (95\% Cl) \\
\hline $\mathrm{A} / \mathrm{A}$ & 194 & 51 & 1.0 & 97 & 1.0 & 110 & 1.0 \\
\hline$A / G$ & 16 & 1 & $0.2(0.02-1.7)$ & 10 & $1.4(0.6-3.2)$ & 10 & $1.4(0.6-2.7)$ \\
\hline $\mathrm{G} / \mathrm{G}$ & 1 & 0 & & 0 & & 3 & \\
\hline
\end{tabular}

of gastric carcinogenesis, which starts with $H$ pylori colonization of the gastric mucosa. Subjects with this polymorphism have an increased risk of severe inflammation and subsequently, development of hypochlorhydria and gastric atrophy, which are regarded as the most important precancerous abnormalities.

We propose that subjects with a pro-inflammatory genetic makeup based on a combination of cytokine gene markers (eg, IL-1 $\beta$, TNF- $\alpha$, IL-10) and the innate immune receptors (eg, TLR4), respond to $H$ pylori infection by creating an environment within the stomach that is chronically inflamed and with reduced acidity. This environment is conducive to the growth of other bacteria within the gastric milieu, leading to sustained inflammation and oxidative/genotoxic stress. Subjects with the same pro-inflammatory polymorphisms may respond in the same exaggerated manner to these non- $H$ pylori bacteria, thus maintaining the pro-neoplastic drive. This may explain why $H$ pylori is not required in the latter stages of gastric carcinogenesis and why it is often absent from gastric tumor tissue.

It is essential to consider the possible mechanism by which the TLR4+896A $>\mathrm{G}$ polymorphism increases the risk of gastric carcinoma and its precursors. The polymorphism was originally described by Arbour et al, ${ }^{13}$ and was associated with hyporesponsiveness to inhaled LPS. Alveolar epithelial cells and macrophages derived from these subjects exhibited decreased response to LPS stimulation. However, this apparent hyporesponsiveness to LPS is actually translated clinically to increased risk of serious outcomes to infections by Gram-negative bacteria and even some viruses. Examples include an increased risk of septic shock, ${ }^{18,27}$ inflammatory bowel disease ${ }^{17}$

Table 5. Combined Effect of IL-1 and TLR4 Polymorphisms on Risk of Noncardia Gastric Carcinoma, Polish and U.S. Studies

\begin{tabular}{lccc}
\hline \multicolumn{1}{c}{ Risk genotype } & $\begin{array}{c}\text { Controls } \\
(\mathrm{n}=630)\end{array}$ & $\begin{array}{c}\text { Cases } \\
(\mathrm{n}=496)\end{array}$ & $\begin{array}{c}\text { Adjusted OR } \\
(95 \% \mathrm{Cl})\end{array}$ \\
\hline Neither & 286 & 115 & 1 (Referent) \\
IL-1 ${ }^{a}$ only & 295 & 299 & $2.4(1.8-3.2)$ \\
$\begin{array}{l}\text { TLR4+896 A/G or } \\
\text { G/G only }\end{array}$ & 23 & 29 & $3.0(1.6-5.4)$ \\
IL-1 and TLR4 & 26 & 53 & $5.0(3.0-8.3)$ \\
\hline
\end{tabular}

$\mathrm{Cl}$, confidence interval; OR, odds ratio.

a Carriage of IL-1B-511T and/or homozygous IL-1RN VNTR allele 2. and severe respiratory syncytial virus bronchiolitis in infants. ${ }^{28}$ The latter association is likely mediated through the respiratory syncytial virus-F protein, which is thought to act as a TLR4 ligand. ${ }^{29}$ It is therefore clear that although the original functional significance of the mutation was defined as hyporesponsiveness to LPS challenge, several lines of evidence indicate that the host suffers serious consequences due to this apparent insensitivity. This is entirely born out in our study as carriers of the $G$ allele had an increased risk of severe gastric damage, manifest as the highest inflammatory and atrophy scores, lowest gastric acid outputs, and ultimately an increased risk of noncardia gastric carcinoma.

How then does a polymorphism that is thought to blunt the response to LPS lead to severe damage in response to $H$ pylori infection? The answer is not entirely clear, but may lie in the nature of the host's overall response to this LPS and peptidoglycan attack. Failure to handle the invasion by appropriately recognizing and activating the necessary pathways may lead to an imbalance of pro- and anti-inflammatory mediators. A very elegant demonstration of this phenomenon was recently reported by Higgins et al. ${ }^{20}$ The authors infected TLR4 defective $\mathrm{C} 3 \mathrm{H} / \mathrm{HeJ}$ mice and their wild-type counterparts $(\mathrm{C} 3 \mathrm{H} / \mathrm{HeN})$ with an aerosol of Bordetella pertussis (a Gramnegative bacterium that causes whooping cough) and monitored the course of the infection and its consequences over several weeks. The course of the infection was more severe in the TLR4-defective than the wild-type mice, and this was associated with enhanced inflammatory cytokine production, cellular infiltration, and severe pathologic changes in the lungs. Most interestingly, Higgins et $\mathrm{al}^{20}$ showed that signaling through TLR4 in response to bacterial infection activated IL-10 production, which promoted IL-10-producing $\mathrm{T}$ cells and controlled inflammatory pathology during infection in normal, but not TLR4-defective mice. It is therefore likely that the severe tissue damage observed in the TLR4-defective mice was due to the deficiency of the anti-inflammatory IL-10, which in turn, accentuated the pro-inflammatory destructive tissue response.

TLRs have the ability to recognize pathogens or pathogen-derived products and initiate signaling events leading to activation of innate host defenses. ${ }^{11}$ Signaling by TLRs induces antimicrobial genes and pro-inflammatory cytokines and chemokines, and leads to acute inflamma- 
tory responses. ${ }^{30}$ Signals that recruit neutrophils and activated macrophages contribute to the killing of microbes, but more importantly, they also lead to activation of adaptive immune responses. In the case of $H$ pylori infection, it is generally accepted that TLRs, in addition to other receptors such as Nod1,31 are at least partly involved in the initial recognition of the bacterium. However, there has been much debate about whether $H$ pylori's LPS is recognized by TLR4 or TLR2 (whose natural ligands include peptidoglycan, lipopeptides, and lipoteichoic acid from Gram-positive bacteria). In particular, there is controversy about whether gastric epithelial cells express TLR4 and whether the LPS of $H$ pylori is involved in the signaling pathways leading to production of proinflammatory cytokines.

Kawahara et $\mathrm{al}^{32}$ showed that guinea pig gastric pit cells expressed TLR4 and other TLRs. Schmausser et $\mathrm{al}^{33}$ confirmed that TLR4, TLR5, and TLR9 were expressed by human noninflamed gastric epithelium and in chronic active $H$ pylori-induced gastritis. More recently, the same authors demonstrated expression of TLR4 and TLR5 on gastric carcinoma cells and precursor lesions (intestinal metaplasia and dysplasia). ${ }^{34}$ In contrast, Backhed et al ${ }^{35}$ found no TLR4 expression in any primary antral cell preparations, and also showed that gastric mucosal recognition of H pylori is independent of TLR4. Similarly, Smith et $a^{36}$ investigated whether TLR2, TLR4, and TLR5 were required for NF- $\kappa \mathrm{B}$ activation and induction of chemokine mRNA expression. They showed that gastric epithelial cells recognize and respond to $H$ pylori infection at least in part via TLR2 and TLR5, and that the $H$ pylori LPS is a TLR2 and not a TLR4 agonist. Similarly, Lepper et $\mathrm{al}^{37}$ demonstrated that $H$ pylori LPS-induced cell activation is mediated through TLR2, and that LPS from some $H$ pylori strains were able to antagonize TLR4. They postulated that the antagonistic activity of $H$ pylori LPS from certain strains, as well as the activation via TLR2, might give the bacterium an advantage over the host by allowing evasion of the innate immune system. Mandell et al, ${ }^{38}$ using LPS derived from clinical isolates, showed that the cytokine-inducing activity of $H$ pylori LPS was mediated by macrophage TLR4.

In summary, it is likely that TLR2 is more relevant to recognition of $H$ pylori LPS by gastric epithelial cells, while TLR4 is relevant in some capacity in the context of macrophage/monocyte or other dendritic cell populations. TLR4 could also be activated by endogenous ligands produced during stress or cell damage. ${ }^{39}$ Such ligands include heat-shock protein 60, EDA domain of fibronectin and hyaluronan, and it is conceivable that severe gastritis with inflammation and matrix turnover could also lead to activation of TLR4. As such, both exogenous factors (eg, $H$ pylori and other bacteria growing in an achlorhydric environment) and endogenous factors (eg, byproducts of tissue damage) could be relevant to TLR4. It appears that genetic polymorphisms in the TLR4 gene have an important impact on this process, and our findings should act as a stimulus for further research into the role that TLRs and other mediators of the innate immune response play in $\mathrm{H}$ pylori-related disease and other Gram-negative bacterial infections.

In conclusion, our findings demonstrate a significant association between the TLR4 Asp299Gly polymorphism and increased risk of noncardia gastric carcinoma and its precursors. Our results further emphasize the importance of genetic variability in the pathogenesis of microbially induced chronic inflammatory diseases, including neoplasia.

\section{References}

1. Parkin DM, Bray F, Ferlay J, Pisani P. Global cancer statistics, 2002. CA Cancer J Clin 2005;55:74-108.

2. Suerbaum S, Michetti P. Helicobacter pylori infection. N Eng J Med 2002;347:1175-1186.

3. Peek RM Jr, Blaser MJ. Helicobacter pylori and gastrointestinal tract adenocarcinomas. Nat Rev Cancer 2002;2:28-37.

4. Macarthur M, Hold GL, El-Omar EM. Inflammation and Cancer II. Role of chronic inflammation and cytokine gene polymorphisms in the pathogenesis of gastrointestinal malignancy. Am J Physiol Gastrointest Liver Physiol 2004;286:G515-G520.

5. El-Omar EM, Carrington M, Chow WH, McColl KE, Bream JH, Young HA, Herrera J, Lissowska J, Yuan CC, Rothman N, Lanyon G, Martin M, Fraumeni JF Jr, Rabkin CS. Interleukin-1 polymorphisms associated with increased risk of gastric cancer. Nature 2000;404:398-402.

6. El-Omar EM, Rabkin CS, Gammon MD, Vaughan TL, Risch HA, Schoenberg JB, Stanford JL, Mayne ST, Goedert J, Blot WJ, Fraumeni JF Jr, Chow WH. Increased risk of noncardia gastric cancer associated with proinflammatory cytokine gene polymorphisms. Gastroenterology 2003;124:1193-1201.

7. Machado JC, Pharoah P, Sousa S, Carvalho R, Oliveira C, Figueiredo C, Amorim A, Seruca R, Caldas C, Carneiro F, SobrinhoSimoes M. Interleukin 1B and interleukin 1RN polymorphisms are associated with increased risk of gastric carcinoma. Gastroenterology 2001;121:823-829.

8. Figueiredo C, Machado JC, Pharoah P, Seruca R, Sousa S, Carvalho R, Capelinha AF, Quint W, Caldas C, Van Doorn LJ, Carneiro F, Sobrinho-Simoes M. Helicobacter pylori and interleukin 1 genotyping: an opportunity to identify high-risk individuals for gastric carcinoma. J Natl Cancer Inst 2002;94:1680-1687.

9. Machado JC, Figueiredo C, Canedo P, Pharoah P, Carvalho R, Nabais S, Castro AC, Campos ML, Van Doorn LJ, Caldas C, Seruca R, Carneiro F, Sobrinho-Simoes M. A proinflammatory genetic profile increases the risk for chronic atrophic gastritis and gastric carcinoma. Gastroenterology 2003;125:364-371.

10. Segal ED, Lange C, Covacci A, Tompkins LS, Falkow S. Induction of host signal transduction pathways by Helicobacter pylori. Proc Natl Acad Sci U S A 1997;94:7595-7599.

11. Pasare C, Medzhitov R. Toll-like receptors: linking innate and adaptive immunity. Adv Exp Med Biol 2005;560:11-18.

12. Takeda K, Akira S. Toll-like receptors in innate immunity. Int Immunol 2005;17:1-14.

13. Arbour NC, Lorenz E, Schutte BC, Zabner J, Kline JN, Jones M, Frees K, Watt JL, Schwartz DA. TLR4 mutations are associated with endotoxin hyporesponsiveness in humans. Nat Genet 2000 25:187-191.

14. Zheng SL, Augustsson-Balter K, Chang B, Hedelin M, Li L, Adam HO, Bensen J, Li G, Johnasson JE, Turner AR, Adams TS, Meyers DA, Isaacs WB, Xu J, Gronberg H. Sequence variants of toll-like receptor 4 are associated with prostate cancer risk: results from 
the Cancer Prostate in Sweden Study. Cancer Res 2004;64: 2918-2922.

15. Chen YC, Giovannucci E, Lazarus R, Kraft P, Ketkar S, Hunter DJ. Sequence variants of Toll-like receptor 4 and susceptibility to prostate cancer. Cancer Res 2005;65:11771-11778.

16. Hellmig S, Fischbach W, Goebeler-Kolve ME, Folsch UR, Hampe J, Schreiber S. Association study of a functional Toll-like receptor 4 polymorphism with susceptibility to gastric mucosa-associated lymphoid tissue lymphoma. Leuk Lymphoma 2005;46:869-872.

17. Franchimont D, Vermeire S, El Housni H, Pierik M, Van Steen K, Gustot T, Quertinmont E, Abramowicz M, Van Gossum A, Deviere $J$, Rutgeerts P. Deficient host-bacteria interactions in inflammatory bowel disease? The toll-like receptor (TLR)-4 Asp299gly polymorphism is associated with Crohn's disease and ulcerative colitis. Gut 2004;53:987-992.

18. Lorenz E, Mira JP, Frees KL, Schwartz DA. Relevance of mutations in the TLR4 receptor in patients with gram-negative septic shock. Arch Intern Med 2002;162:1028-1032.

19. Kiechl S, Lorenz E, Reindl M, Wiedermann CJ, Oberhollenzer F, Bonora E, Willeit J, Schwartz DA. Toll-like receptor 4 polymorphisms and atherogenesis. N Engl J Med 2002;347:185-192.

20. Higgins SC, Lavelle EC, McCann C, Keogh B, McNeela E, Byrne P, O'Gorman B, Jarnicki A, McGuirk P, Mills KH. Toll-like receptor 4-mediated innate IL-10 activates antigen-specific regulatory $T$ cells and confers resistance to Bordetella pertussis by inhibiting inflammatory pathology. J Immunol 2003;171:3119-3127.

21. Price AB. The Sydney System: histological division. J Gastroenterol Hepatol 1991;6:209-222.

22. El-Omar EM, Oien K, Murray LS, El Nujumi A, Wirz A, Gillen D, Williams C, Fullarton G, McColl KE. Increased prevalence of precancerous changes in relatives of gastric cancer patients: critical role of H. pylori. Gastroenterology 2000;118:22-30.

23. Chow WH, Swanson CA, Lissowska J, Groves FD, Sobin LH, Nasierowska-Guttmejer A, Radziszewski J, Regula J, Hsing AW, Jagannatha S, Zatonski W, Blot WJ. Risk of stomach cancer in relation to consumption of cigarettes, alcohol, tea and coffee in Warsaw, Poland. Int J Cancer 1999;81:871-876.

24. Gammon MD, Schoenberg JB, Ahsan H, Risch HA, Vaughan TL, Chow WH, Rotterdam H, West AB, Dubrow R, Stanford JL, Mayne ST, Farrow DC, Niwa S, Blot WJ, Fraumeni JF Jr. Tobacco, alcohol, and socioeconomic status and adenocarcinomas of the esophagus and gastric cardia. J Natl Cancer Inst 1997;89:1277-1284.

25. Lorenz E, Frees KL, Schwartz DA. Determination of the TLR4 genotype using allele-specific PCR. Biotechniques 2001;31: 22-24.

26. Royall RM. Model robust confidence intervals using maximum likelihood estimators. Int Stat Rev 1986;54:221-226.

27. Ouburg S, Mallant-Hent R, Crusius JB, van Bodegraven AA, Mulder CJ, Linskens R, Pena AS, Morre SA. The toll-like receptor 4 (TLR4) Asp299Gly polymorphism is associated with colonic localisation of Crohn's disease without a major role for the Saccharomyces cerevisiae mannan-LBP-CD14-TLR4 pathway. Gut 2005;54:439-440.

28. Tal G, Mandelberg A, Dalal I, Cesar K, Somekh E, Tal A, Oron A, Itskovich S, Ballin A, Houri S, Beigelman A, Lider O, Rechavi G, Amariglio N. Association between common Toll-like receptor 4 mutations and severe respiratory syncytial virus disease. J Infect Dis 2004;189:2057-2063.

29. Kurt-Jones EA, Popova L, Kwinn L, Haynes LM, Jones LP, Tripp RA, Walsh EE, Freeman MW, Golenbock DT, Anderson LJ, Finberg RW. Pattern recognition receptors TLR4 and CD14 mediate response to respiratory syncytial virus. Nat Immunol 2000;1:398401.

30. Janeway CA Jr, Medzhitov R. Innate immune recognition. Annu Rev Immunol 2002;20:197-216.

31. Viala J, Chaput C, Boneca IG, Cardona A, Girardin SE, Moran AP, Athman R, Memet S, Huerre MR, Coyle AJ, DiStefano PS, Sansonetti PJ, Labigne A, Bertin J, Philpott DJ, Ferrero RL. Nod1 responds to peptidoglycan delivered by the Helicobacter pylori cag pathogenicity island. Nat Immunol 2004;5:1166-1174.

32. Kawahara T, Kuwano Y, Teshima-Kondo S, Sugiyama T, Kawai T, Nikawa T, Kishi K, Rokutan K. Helicobacter pylori lipopolysaccharide from type I, but not type II strains, stimulates apoptosis of cultured gastric mucosal cells. J Med Invest 2001;48:167-174.

33. Schmausser B, Andrulis M, Endrich S, Lee SK, Josenhans C, Muller-Hermelink HK, Eck M. Expression and subcellular distribution of toll-like receptors TLR4, TLR5 and TLR9 on the gastric epithelium in Helicobacter pylori infection. Clin Exp Immunol 2004;136:521-526.

34. Schmausser B, Andrulis M, Endrich S, Muller-Hermelink HK, Eck M. Toll-like receptors TLR4, TLR5 and TLR9 on gastric carcinoma cells: an implication for interaction with Helicobacter pylori. Int J Med Microbiol 2005;295:179-185.

35. Backhed F, Rokbi B, Torstensson E, Zhao Y, Nilsson C, Seguin D, Normark S, Buchan AM, Richter-Dahlfors A. Gastric mucosal recognition of Helicobacter pylori is independent of Toll-like receptor 4. J Infect Dis 2003;187:829-836.

36. Smith MF Jr, Mitchell A, Li G, Ding S, Fitzmaurice AM, Ryan K, Crowe S, Goldberg JB. Toll-like receptor (TLR) 2 and TLR5, but not TLR4, are required for Helicobacter pylori-induced NF-kappa B activation and chemokine expression by epithelial cells. J Biol Chem 2003;278:32552-32560.

37. Lepper PM, Triantafilou M, Schumann C, Schneider EM, Triantafilou K. Lipopolysaccharides from Helicobacter pylori can act as antagonists for Toll-like receptor 4. Cell Microbiol 2005;7: $519-528$

38. Mandell L, Moran AP, Cocchiarella A, Houghton J, Taylor N, Fox JG, Wang TC, Kurt-Jones EA. Intact Gram-negative Helicobacter pylori, Helicobacter felis, and Helicobacter hepaticus bacteria activate innate immunity via toll-like receptor 2 but not toll-like receptor 4. Infect Immun 2004;72:6446-6454.

39. Pasterkamp G, Van Keulen JK, De Kleijn DP. Role of Toll-like receptor 4 in the initiation and progression of atherosclerotic disease. Eur J Clin Invest 2004;34:328-334.

Received January 16, 2006. Accepted November 30, 2006

Address requests for reprints to: Professor Emad M. El-Omar, MD, Department of Medicine and Therapeutics, Aberdeen University, Institute of Medical Sciences, Foresterhill, Aberdeen, AB25 2ZD, Scotland. e-mail: e.el-omar@abdn.ac.uk; fax: (44) 1224-555766.

Supported by a grant from Cancer Research UK (C8969/A3868), and by the Intramural Research Program of the National Cancer Institute, National Institutes of Health. 